\title{
UK POLICY OPTIONS AND THE SOUTH ATLANTIC
}

\section{Martin Robson ${ }^{1}$}

\section{Introduction}

The true value of history is to provide a relevant backstory for the contemporary world. With regards to policy and strategy there are two aspects to this: I) analysis how we got to where we are and 2) if we can make some recommendations, based upon that analysis, as to where we might and should be going. If history does not have something to say to the contemporary world then it is just stuff that has happened. Yet we should not overstate the case. Neither history or theory can provide us with a crystal ball to predict the future. But it can provide us with a starting point, and perhaps, at best, a few handrails as to long-term trends that allow us to start to formulate and then implement reasoned policy. Understanding the past is the necessary foundation for effective analytical tools (such as SWOT ${ }^{2}$ and DIME3), which are the precursor for effective scenario planning. That is very much a case of assessing most likely / least likely or best case / worst case to the question of 'if we do this what might happen?' (Ringland 2006) Scenario planning has utility for the academic, trying to scope out how policy decisions taken might play out over the long term (Oliver and Williams 20I6). So while this article is specifically about contemporary UK policy options in the South Atlantic ${ }^{4}$, I plead some indulgence as a historian to explain how I commenced thinking about the subject.

Some of my previous work assessed Britain's relationship with South

I Martin Robson is a professor in Strategic Studies at the University of Exeter. PhD from the Department of War Studies at King's College London. E-mail: m.robson@exeter.ac.uk.

2 Strengths / Weaknesses / Opportunities / Threats.

3 Diplomatic / Information / Military / Economic.

4 Based around a timescale of presentation as a conference paper in late 2016 and writing it up in spring 2017 . 
America, particularly British political decision making at a time when British goods and trade were largely excluded from Europe due to Napoleon's Continental Blockade (Robson 20I0). That attempt to deny the markets of Europe to British trade led to the controversial, at times, forcible, opening up of new markets in South America to compensate for the trade lost with Europe. British exports to areas in the Americas outside of the USA jumped from $£ 7.8$ million in 1805 to just over $£$ I6.5 in I808. South America, in DCM Platt's view, provided 'the main outlet for new trade during a period in which the important European and North American markets were particularly lean' (Platt I972, 28, Table I). At a time of uncertainty over the nature of BREXIT, such historical analogy prompted me to assess the potential importance of Latin America to British trade post-BREXIT.

An initial consideration was if that was a realistic proposition, given that the world today is so different from that of two centuries ago but also, within the scope of a conference assessing 'South Atlantic Security: Actors, Interests and Strategies' what exactly were the options for the UK as an actor with vested national interests? What are the policy options and what strategies can be implanted to achieve national interests in the South Atlantic?

\section{BREXIT: The elephant in the room?}

In June 2015 the UK Office for National Statistics highlighted the fact that UK trade with the EU had been declining in importance over a number of years, compared with non-EU trade. It concluded that 'strong economic growth in many developing economies outside the EU has resulted in nonEU economies growing in importance to UK trade, with the proportion accounted for by the EU falling consistently since I999, despite the value of EU trade increasing'. So in that sense maybe BREXIT was actually part of a longer economic trend with non-EU trade becoming more important, a process that is likely to be continued after BREXIT (ONS 20I5).

Yet, Europe does remain important as UK trade figures for 2015 show. UK imports from the EU in that year were $£ 290,62 \mathrm{Im}$ with imports from the rest of the world of $£ 229,245 \mathrm{~m}$. Exports, on the other hand, were $£ 259,955 \mathrm{~m}$ with the Rest of the World and $£_{230,03 I}$ with the EU. Within the EU Britain's largest trading partner is Germany, with an imbalance caused by the UK importing $£ 70.4 \mathrm{bn}$ and exporting $£ 48$.5 bn worth of trade. The UK imports more from Germany than it does from the USA, with imports from the USA at $£ 59.3$ bn yet the UK exports $£ 96.4$ bn worth of trade to the USA. Clearly, for the UK to maintain a prosperous economy it must maintain its trade 
with the USA and with EU countries like Germany. In context, UK trade with China once again produces a deficit, with imports at $£ 38.4$ bn and exports at $£^{1} 6.7 \mathrm{bn}$. Trade with South America is, by comparison, small fry in pure economic terms though since 201 I the UK has maintained a trade surplus with South America. The key economic relationship is with Brazil, which accounts for 69.I per cent of the UK trade with South America. Trade with Brazil produces a modest surplus with exports of $£ 3$.8bn set against imports of $£ 2.5 \mathrm{bn}$. Brazil is by far the most important UK trading partner in South America, with Colombia (imports $£ 0.7 \mathrm{bn}$, exports $£$ o.6bn), Argentina (imports $£ 0.7 \mathrm{bn}, \mathrm{ex}-$

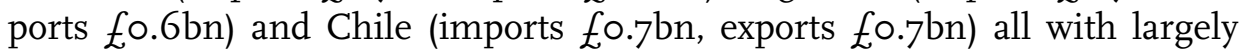
similar figures for 20I5. Globally, Brazil sits as the UKs $27^{\text {th }}$ largest export destination and in return Brazil is the 32nd largest import partner (ONS 20I7,I). Moreover, Brazil is a destination for UK investment, with assets held by UK investors in Brazil between 2010 and $201 \mathrm{I}$ doubling from $£ 6.4$ bn to $£$ I4.Ibn. UK investment in Brazil in 20I4 was £I4.7bn (ONS 20I7, 2).

More up to date figures show the UKs top Io trading partners in January 2017 are largely the same countries that were in the top Io in January $20 \mathrm{I} 6$ before the BREXIT vote of 23 June: USA, Germany, France, Netherlands, Irish Republic, China, Belgium, Italy and Spain with Switzerland appearing on the list of top ten export destinations and Norway on the top ten of UK imports. Between January 2016 and January 2017 have Non-EU exports increased by $£ 4$.Ibn or 35 per cent for a monthly total of $£$ I5.5bn for January 2017 . NonEU imports have also grown over the year with a growth of 28 per cent up to $£$ I8.6bn worth of imports in January 2017 . For EU exports the increase has been $£^{2}$.3bn (22 per cent) over the same timescale to a monthly total of $£^{\mathrm{I} 2.8 b n}$ for January 2017 . Over the same year, EU imports increased by I7 per cent ( $£ 2.8 \mathrm{bn})$ to a monthly total of $£$ I9.5 bn (HMRC 20I7).

Taking a slightly longer view, UK exports to the EU have fallen from $54.8 \%$ in 1999 to $44.6 \%$ in 2014 . This in part may be down to the EU's falling share of global GDP, $30 \%$ in 1993 to $24 \%$ in 2013 , in turn caused by the fast developing Brazilian, Russian, Indian and Chinese economies (Office for National Statistics 2015) So while the UK has been increasingly trading with emerging and advanced economies from outside the EU, in 2016 nearly $50 \%$ of exports went to six countries the United States, Germany, France, Netherlands, Republic of Ireland and China with over 50\% of the UK's imports of goods coming from 6 countries: Germany, China, United States, Netherlands, France and Belgium (ONS 2017, 3).

The point is, BREXIT can be seen as part of a longer trend in changing global economics, but within that there remains some certainty about the UK's vital trading relationships. So, what might BREXIT really mean for the 
$\mathrm{UK}$ ?

\section{What has not changed?}

Whatever the future character of the UK's relationship with the EU it is still a $\mathrm{P}_{5}$ member of the UN and a key player in the NATO Alliance. Historically, when the UK has been isolated from Europe in hard security terms it has looked overseas for security. That was the case, at least in terms of economic security, with British interest in Latin America already noted above. In I940-45 it was to the United States that the UK looked, for hard security in the sense of the military alliance when both powers signed the 'Declaration by United Nations' on I January I942 at the ARCADIA Conference, and then in economic terms with the beginning of the Lend-Lease programme. The linkages between economics and security have been enshrined into UK policy. As the 2015 UK National Security Strategy and Strategic Defence and Security Review made clear in the foreword from the Prime Minister David Cameron: 'Our national security depends on our economic security, and vice versa. So the first step in our National Security Strategy is to ensure our economy is, and remains, strong' (HMSO NSS/SDSR 20I5, 5).

Post BREXIT the UK will still have some kind of trading relationship with its major European trading partners, Germany being particularly important. But it will also look to expand UK trade with other key trading partners beyond Europe; here the UKs membership of the G2O - alongside Brazil and Argentina - may prove immensely valuable (ONS 20I6). If, however, enhancing UK trade links with South American countries is to be a post-BREXIT part of British policy then there are some challenges to be addressed.

\section{UK trade}

The raw figures of UK trade with South America have been noted above, but the UK lags behind other nations in trading with the region. With Brazil accounting for nearly half of South America's GDP and the major prize for enhancing British trade, signs are not promising. Up to 2010 the USA was Brazil's major trading partner, since then China has led the trade, accounting for around I $8 \%$ of Brazilian exports and imports, with the US coming second and then in terms of exports, Argentina, and imports, Germany (UN data 20I5). The situation has been fully recognised in the UK with Robert Capurro, Chief Executive of Canning House, noting in August 2016 that the UK was 'terribly far behind our European, Chinese and American competi- 
tors....We're punching well below our weight' (Yeomans 20I6). With the USA and China now locked in scramble for Latin American markets, the UK risks being caught between those two trading superpowers; both of which will be integral to making a success of Brexit.

One key question for UK policy makers has to be whether to reinforce success by focussing on Brazil or diversifying and adding resilience to UK trade by enhancing economic links with other South American countries. The former could possibly build upon existing bilateral relations with Brazil, the latter would inevitably involve some kind of discussion about the role of Southern Common Market, MERCOSUR'. Here the UK would be entering into direct competition with the EU which sees Mercosur as an important trading partner. Since 20I0 the EU has been progressing with negotiations to implement a free trade agreement with MERCOSUR, and which post-BREXIT the UK would be excluded. Yet, this wider approach has not stopped the EU from engaging in bilateral partnership and cooperation agreements with the key MERCOSUR countries of Argentina, Brazil, Paraguay and Uruguay. For those countries within the MERCOSUR context, the EU is the most important trading partner accounting for $2 \mathrm{I} \%$ of trade. So not only will the UK be in competition with the USA and China for key South American markets, it will also be in competition with the EU. In 2015 the EU exported $€_{4} 6 \mathrm{bn}$ and imported $€_{42}$ bn from MERCOSUR and exported 2obn of commercial services while investing $€_{3} 87 \mathrm{bn}$ in the region, making the $\mathrm{EU}$ the largest foreign investor in MERCOSUR (European Commission 20I7).

If the UK was to enhance non-Brazilian trade then Argentina seems a logical choice. Figures from Oxford Economics for the Fourth Economic Quarter of 2016 show the Argentine economy was finally growing after a deep recession in 20I5, with a continued forecast of GDP growing by $2.5 \%$ in 20I7, mainly due to the domestic economic policies of President Macri (Oxford Economics 20I6). Yet, as I noted before, there is more to national interests than just economics. Trade and finance must be contextualised with political and strategic challenges - they cannot be separated out. The future of the UKs economic interests in South America will be been shaped by some harsh realities.

\section{The UK and the South Atlantic: The strategic reality}

The UK has major political and strategic commitments in the South

5 Member countries: Argentina, Brazil, Paraguay, Uruguay, Venezuela. Associate Members Countries Bolivia, Chile, Peru, Colombia, Ecuador and Suriname. 
Atlantic that entail risk in future policy making. Of course, risk is a multifaceted concept and involves opportunity as well as threat. The UK's wider political and strategic commitments in the South Atlantic involve more than just the Falkland Islands, there are the Overseas Territories (OT) of Saint Helena, Ascension \& Tristan da Cunha and South Georgia and the South Sandwich Islands. In 2015 the UK government reiterated its commitment to the OTs:

The people of the Overseas Territories have a right to safety, security and self-determination. They are free to maintain a constitutional link if this is their choice. The UK stands ready to protect the Territories from external threats, ensuring their self-determination. In particular, the UK supports the efforts of the peoples of Gibraltar and the Falklands Islands to determine whether to remain a British Overseas Territory (UK Government 20I5).

BREXIT may have altered some aspects of the debate but it has not changed this basic element of UK policy. Alongside the OTs the UK also has responsibility for British Antarctic Territory as well as strong links with six African members of the Commonwealth of Nations with South Atlantic coastlines: Sierra Leone, Ghana, Nigeria, Cameroon, Namibia and South Africa.

If the UK is to formulate and enact effective policy then UK interest in the South Atlantic needs to be made and delivered with an understanding and in a context far broader than thinking about trade, politics and strategy. It needs a more wholistic view, perhaps more akin to Brazilian thinking about its relationship with the South Atlantic and its community of nations. This approach is particularly important for Brazil, as the regional leader, with regard to its reliance upon maritime oil and gas, and the unexplored bonanza that may exist in the pre-salt deposits and its continental shelf; a subject also of immense interest to countries like Nigeria (Brozoski and Padula 2016, 99IO०) I am not suggesting the UK slavishly follows the Brazilian approach to the South Atlantic as a maritime environment enshrined in the concept of the 'Blue Amazon', launched by the Brazilian Navy in 2004 and formally trademarked in 2010 (Wiesebron 2013, IO2). Nor does the UK just require a structural / ideological view as encapsulated in the 20I3 Brazilian led reconstitution of the Zone of Peace and Cooperation of the South Atlantic (ZPCSA) which outlines maritime cooperation in the South Atlantic between signatories (Duarte 2016, 99).

Instead the UK requires a wholistic concept of the South Atlantic and the UKs interests in the region beyond the compartmentalised focus on the three distinct parts: the OTs, primarily the Falkland Islands, Antarctica and 
West Africa. In essence, they are the same. So while the UK is opposed to ZPCAS, at least in its treaty form, that does not mean to say that such an approach does not have utility for thinking about UK interests and options.

\section{The UK as a South Atlantic actor}

So while it is easy, from a structural sense, to look at those three areas individually all three are inherently linked physically, by the sea, but also economically, culturally and politically. For example, the UK's overseas territories naturally encompass relations with Argentina, and Brazil as the regional leader with a huge interests in the maritime domain. Involving Brazil also means the inclusion of those shared West African interests. UK interests cannot be seen in isolation from Argentine and Brazilian interests - strategy is, after all, relative - other stakeholders have an interest and are acting on the same stage. That is why the UK requires a conceptual wholistic view of the South Atlantic. In that context a number of questions are not readily answered. What kind of actor does the UK want to be in international politics? What type of actor can the UK be? What roles does it want to fulfil and what can it fulfil?

In terms of the UK's role as an actor on the European stage, that is currently undergoing renegotiation due to BREXIT and played a part in the 20I7 UK General Election. This has all impacted upon the range of identity and policy options available. So while the BREXIT referendum result cannot be ignored, and Article 50 has been triggered, discussion continues about what might cause a volte-face in the UK's approach to BREXIT. Whatever the outcome of BREXIT the UK will still have some kind of relationship with Europe, through NATO and through bilateral trade. It is easy, especially for the mainstream media, to paint all this in absolute terms; we just need to think of the terminology of BREXIT - leave or remain - but it is far more complex than that. What might be more useful is if we can identify discernible patterns or role orientation. For example, since the end of the Cold War the UK, as a Western Liberal Democracy and a member of the United Nations Security Council $\mathrm{P}_{5}$ has tended to view its intervention in the affairs of another state in (some, but not all) humanitarian crises in the sense of being a 'force for good' in the world. The UKs apparent desire to intervene for humanitarian reasons has produced a pattern of behaviour. In fulfilling this desire was the UK acting out its role, or has ad-hoc intervention created a role for the UK? Why has it not intervened in all humanitarian crises that it could have done? If it does have a role as a 'force for good' then policy/strategy/public opinion/ parliament have exerted influence to stop that role being enacted, compare intervention in Libya in 20II with non-intervention in Syria in 2013. 
In relation to the subject under discussion here, there are patterns to UK involvement in the South Atlantic and such roles are important. From the late I96os through the I970s the UK assumed that while, following a process of decolonisation, it retained some colonial interests, there would be no need to defend its overseas territory without help from allies, in particular the USA. Instead, British role orientation was as a good ally within the construct of NATO. That involved investing in nuclear deterrence, the British Army of the Rhine and anti-submarine warfare in the North Atlantic. There would be no need for a military capacity for global power projection as the UK did not envisage it playing such a role. This process culminated in the I98I Defence White Paper (the so called Nott Review) to further configure the UK armed forces for the perceived role (McCourt 20I4, I38). The consequence was that the UK was signalling that not only did not envisage playing a role in the South Atlantic, it was removing its military capability to do so. That, at least, was how it was read in Buenos Ayres, adding to the frustration felt by the Argentine Junta at the lack of progress in a negotiated settlement in line with United Nations General Assembly Resolution 2065 (Freedman and Gamba-Stonehouse I99I, chapter I).

Revisiting the events in the run up to and of 1982 is beyond the scope here. But what is important for UK policy options in the South Atlantic is how the UK's interests and capabilities are viewed in that region. Here the UK House of Commons Public Administration Select Committee's publication Who does UK National Strategy? Further Report, noted in $201 \mathrm{I}$ that 'strategic aims cannot be set out or adjudicated without an articulated account of who 'we' are and what we believe both about ourselves and the world' (HoC PASC 2OII, 4) The thinking in that report was partly addressed in chapter I of the 2015 National Security Strategy and Strategic Defence and Security Review entitled 'Our Vision, Values and Approach' (HMSO NSS/SDSR 2015, 9). The question is how does the UK project a vision of itself and its values in the South Atlantic now and for the foreseeable future?

Role theory and its utility for analysis of foreign policy can be traced back to the early i970s (Holsti I970) Time and space prevent a detailed historiography of the subject (Gaskarth 20I4, I). Perhaps of best utility here are Margaret Hermann's roles and drivers (Hermann i987, I34).

Table 1: Margaret Hermann's Foreign Policy roles and drivers

\begin{tabular}{|c|c|}
\hline Policy Role & Policy Driver \\
\hline Expansionist & Power \\
\hline Active independent & Autonomy \\
\hline
\end{tabular}




\begin{tabular}{|c|c|}
\hline Influential & Influence in the intl system \\
\hline Mediator/integrator & Solutions to problems \\
\hline Opportunist & Popular approval \\
\hline Developmental & Development of the state \\
\hline Isolate & Isolation \\
\hline
\end{tabular}

In this sense, status is key; in other words the status of a country on the international stage. For those nations aspiring to play the great power role that involves a duty / desire to mediate / influence international events. For example, in I945 the Great Powers created the United Nations Security Council and concept of the Permanent Members of the council, the USA, Russia, China, France and the UK. That probably did reflect global power, now the determinant of great power status is somewhat more diffuse than just membership of the P5. Is, for instance, the EU a great power based upon its economic strength?

This is important for, as James Gaskarth has noted, role orientation: 'represents the highest order of strategic thinking in foreign policy'. He asks that question for the UK set against economic constraints and pressures and rival power. Much debate in the literature centres on the ability, or not, of policy makers to make conscious decisions to change roles. Gaskarth uses the example of the United States which, given its global trade and interactions, would struggle to follow an isolationist policy. What is possible, however, is the ability for policy makers to make a strategic choice as to which role orientation they can adopt to further national interests in a given context. As Gaskarth argues, while there are limitations, 'there exists the scope for British foreign policy makers to examine the range of potential role orientations available to a state such as the UK and explore the likely benefits and costs of each' (Gaskarth 20I4, 2; 45-8).

While Gaskarth applies this to the role orientation of the UK exerting influence in the international system in a somewhat general manner, this is of much utility in focussing in on tangible UK interests, in this case in the South Atlantic, and which roles might best further them.

\section{Role scenarios}

Role theory allows the identification of how states interact on the international stage through relations with other states and membership of international organisations which produces norms in how a state acts and communicates. Gaskarth uses the example of how membership of an organisation like 
NATO prescribes a state the role of 'reliable ally' (Gaskarth 20I4,I). Knowledge of this allows the student to identify action scripts which predict, in theory, the policy or strategy enacted in a given context. For example, Article V of the North Atlantic Treaty states that 'an armed attack against one or more of them in Europe or North America shall be considered an attack against them all' (NATO I949) The event, an armed attack, produces an action script for all members of the alliance as they are all 'reliable allies' by being part of the alliance. Without the action script the alliance would lack credibility.

With referenced to the UK in the South Atlantic, this was discussed in I982 in terms of the UK response to the Argentine invasion. Admiral Sir Henry Leach, the First Sea Lord in I982, was asked by Prime Minister Margaret Thatcher that if the islands were captured by Argentina, 'do you really think that we can recapture them?'. Leach's response has entered naval folklore but also points to his perception of the UK's role in the world and therefore production of an action script and is worth repeating here:

...my reaction was that yes, we could recapture, it would be a high-risk venture, but I then stuck my neck out (which was beyond my terms of reference really) and said, 'And we should'. She was on to that like a hawk and said, 'Why do you say that?' so I said, 'Because of we do not, if we muck around, if we pussyfoot, if we don't move very fast and are not entirely successful, in a very few months' time we shall be living in a different country whose word will count for little'. She gave me a very cold look and then cracked into a grin, because it was exactly I think what she wanted to hear (Falklands War 2002, 29; Griffin 2005, I35).

Leach's view does still have some relevance to the way the UK views itself acting on the world stage today, but the emphasis recently has been on the Falkland Islanders who voted on IO-II March 2013 to retain their status as a British Overseas Territory. After providing the islanders with the opportunity to express their wishes, the UK government now has a fundamental duty of care to look after their interests, security and economic development. This will have increasing importance as the UK approaches BREXIT. The EU is the most import trading partner of the Falkland Islands, valued around $\mathcal{E}_{\mathrm{I}} \mathrm{O}$ million per year. That is $70 \%$ of the Falkland Islands GDP (Benwell and Pinkerton $2016, \mathrm{II})$. Moreover, trading with the EU and being a part of the EU as a British Overseas Territory has provided an element of support to the islands, with the EU remaining neutral in the light of the Argentine claims. 
Isolate

The first potential role option is that of Isolation. Given the outcome of and debate following the BREXIT referendum of 2016 the UK could be seen as taking a more isolationist stance with regard to Europe. While that might be true, to some degree, in a political sense, in an economic sense the UK will continue to trade heavily with European nations. So if BREXIT is not really isolationism, then we cannot expect an isolationist approach to other parts of the world.

It is fair to say that the UK gave appearances or signals of an isolationist approach to the South Atlantic during the years prior to I982 when the region was not in British strategic thinking. Sir John Nott, Secretary of State for Defence in I982, later told a witness seminar in 2002 'As for deterrence in the Falkland Islands, I never ever thought about it. I didn't even know, frankly, where the Falkland Islands were!' (Falklands War 2002, I8). For Lord Carrington, the Foreign Secretary in I982, 'The Falklands represented no vital strategic or economic interest for Britain' (Freedman and GAmba-Stonehouse I99I, I4). Given the legacy of I982, UK investment in defence of the Falkland Islands since then and the 2013 referendum it is fair to say that the islanders enjoy a far higher profile in the UK than in I982. With the islanders choosing to continue to look to the UK in 20I3, any isolationist policy from the UK in the South Atlantic would in effect signal a withdrawal from UK national interests in the region and its Overseas Territories. That might be an attractive option for a UK government looking to make quick savings to the defence budget. The UK has withdrawn from expensive overseas defence commitments before. In the late I96os the Wilson Government enacted a decision to withdraw, in a strategic sense, British defence commitments from East of Suez as part of a longer assessment of Britain's changing role in the world (Dockrill 2002). Then there was the highly visible handover of Hong-Kong in I997. So the UK has 'withdrawn' from overseas commitments before and to do so in the South Atlantic might lead to enhanced standing in Latin America for the UK as a post-colonial power, perhaps leading to economic benefits in trade relations with the MERCOSUR countries.

On the other hand, such a policy would carry immense domestic political risk for any government considering such a move. Proposed withdrawal from the South Atlantic would raise serious concerns from the Falkland Islanders, UK media, the Armed Forces and sections of the public regarding the security of the Falkland Islands (Swinford 20I5). Moreover, such a retreat could only be seen as encouragement for Argentine claims in the region which also includes Antarctic territory. There would also be the danger of a 
domino effect with other contested UK territories, such as Gibraltar, coming under renewed scrutiny where Brexit has clearly given impetus to Spanish belligerence over the 'Rock' (Clegg 2016, 552).

Another factor at play here is the wider South Atlantic strategic context where the challenges range from transnational crime, narcotics, piracy, smuggling to climate change and resource extraction (Abdenur and Souza Neto 2013, 7). These are global challenges, not just related to any one region or nation, and as such will require cooperative solutions. Moreover, as a Permanent Member of the UN Security Council and with strong links to a number of West African countries, the UK cannot afford to not have an interest in the South Atlantic. In that sense the UK hopes to have influence in the international system to maintain the rules based international order (HMSO NSS/SDSR 20I5, 20). That means the UK must have faith in the international systems which oversee that order, in particular the United Nations. Here, of course, there is an ideological conflict between the actions and intent of the Committee of 24 (Special Committee on Decolonization) whose object is the obtaining of independence for what it terms colonial countries and peoples and Article I of the UN Charter, which states 'respect for the principle of equal rights and self-determination of peoples' (UN I945). That latter aspect is what the Falkland Islanders expressed during the 2013 referendum. The UK could be accused of only upholding international norms in areas of self-interest. That charge could, however, also apply to Brazil's request to the UN to expand its Continental Shelf by $900,000 \mathrm{~km} 2$ to include possession of any natural resources to be found under the sea bed (Duarte 2016, 98).

\section{Opportunistic Partner}

UK foreign policy has and, to a degree, remains, about preserving the status quo, but that does not really help solve any of the challenges faced in the South Atlantic. That is not a strategy of passive detachment, of isolation. What this approach does do is grant UK policy makers the ability to wait and see, a strategy of opportunism, which is a strategy of sorts. Moreover, it has had some benefits, especially with regard to Argentina. The Falkland Islands have been depicted as a strategic gateway for the UK (Dodds 20I2:I, 6), an open wound souring UK relations with South America (Dodds 20I2:2) or a frozen conflict akin to the situation in Cyprus or Kashmir (Mitchell 20I4, I90). None of these analogies are really particularly insightful for the strategist. Instead, a recent thawing of relations between the UK and Argentina have been largely due to changes in Argentine domestic politics, specifically the fall of Cristina Kirchner and election of President Mauricio Macri set against the context of 
the UK willingness to take advantage of that change following BREXIT to develop economic and diplomatic links. If that is the case, the problem for British policy is that Argentina could (though the evidence seems to suggest it will not in the short term) once again engage in economic sparring with the UK in order to obtain political leverage over the Falkland Islands especially if the domestic political makeup changes in Buenos Aires once again.

Under the leadership of first Néstor then Cristina Kirchner, the years 2003-20I5 witnessed a war by other means over the Falkland Islands, with every opportunity utilised to raise the Argentine claim. Moreover, this period included some novel/bizarre publicity stunts alongside diplomatic efforts through the UN and economic warfare against the islanders (Dodds 2012:2). All aspects of state power short of military action were used to try and change the political status quo. Argentine unwillingness to take the military option during these years may be more reflective of the poor state of Argentine military forces after years of neglect than a desire to act more responsibly domestically and internationally than the military junta in I982 (IISS 20I7). With Argentina and Brazil both reliant upon a globalised trading environment and set against a declining Brazilian economy with which Argentina is heavily dependent upon, a return to the economic warfare policies towards the Falkland Islands seems unlikely under President Macri. With regard to offshore hydrocarbons, Argentina cannot go it alone, and there remains scope for revenue sharing between the Falkland Islanders, the UK and Argentina in line with the Joint Declaration on Cooperation in Offshore Activities in the South West Atlantic which was signed in 1995 and from Argentina withdrew in 2007. This withdrawal from collaboration was also evident in Buenos Aires pulling apart the I999 Joint Statement which outlined cooperation over access, air travel and fishing.

Such collaborative initiatives are now back on the table, with the UK and Argentine governments issuing a new Joint Statement on areas of mutual cooperation on I4 September 2016 (UK Govt 20I6:I). It is worth reiterating that this has less to do with BREXIT and more to do with changes in Argentine domestic politics. In May 2016 Lord Price, the UK Trade and Investment Minister, led the first UK trade mission to Argentina for a decade stating that: 'The growing economies of Latin America offer huge opportunity for British business' (UK Govt 20I6:2). Faced with possible exclusion from European markets, is this British economic opportunism akin to the period I806-1808? It seems so, and it is more than just words. Lord Price's trade mission laid the foundations for a visit to Argentina in September 2016 by Foreign and Commonwealth Office Minister Sir Alan Duncan. Talks were productive with both governments agreeing to work towards lifting restrictions that have inhibited 
the exploitation of oil and gas, the free passage of shipping and fishing around the islands. Also discussed were other areas of possible cooperation including much needed foreign investment into the Argentine economy, science and technology, as well as approaches to tackling corruption and organised crime (UK Govt 20I6:3).

While the sovereignty of the Falklands Islands was not discussed, with both the UK and Argentina keen to talk on areas of collaboration, the issue of the Argentine claim will not go away written as it is into the Argentine political constitution. In March 2016 the UN Commission on the Limits of the Continental Shelf (CLCS) placed the Falkland Islands in expanded Argentine waters. This, as the UK government pointed out, did not impinge in any way upon sovereignty, over which the CLCS has no jurisdiction, while pointing out the UN had recognised that in considering the Argentine submission for an expanded continental shelf it did consider this to include claims relating to the Falkland Islands (UK Govt 20I6:4). On I6 October 20I6 Argentina complained about planned UK military exercises in the Falkland Islands while President Macri backtracked from a claim he had discussed 'sovereignty' with UK Prime Minister Theresa May (Goñi 20I6). Set against that in November 2016 the Argentine Foreign Minister Susana Malcorra was reported as stating 'we can't deny the existence of the Malvinas inhabitants with whom we have been distanced for too long', thereby starting to recognise that under the UN the Falkland Islanders do have the right to self-determination (MercoPress 2016). This had always been denied by Argentina.

So while there are areas of continued disagreement, what is clear with the Macri regime is that mutually beneficial Business can be done around the issue of the Falkland Islands. This will become more important post BREXIT, given the fact that 70 per cent of Falkland Islands GDP depends on access to the EU markets. With the Falkland Islands recognised as a UK Overseas Territory, BREXIT has the potential to leave the islanders weakened but clearly the UK government have been acting to strengthen the position of the islanders as part of a wider approach to UK-Argentine relations. What this means is that while the UK Overseas Territories in the South Atlantic do have the potential to impinge upon the UK being seen as a regional partner, the UK is actively aware of this and is focussing on economic collaboration to foster closer links with Argentina.

In a political sense, there will be no dialogue on sovereignty unless the Falkland Islanders want it. This is in stark contrast to thinking in the run up to I982 where the concerns of the islanders hardly counted. Now, at least from a UK perspective, the Falkland Islands do not have to dominate the UK-Argentina relationship, an understanding that also seems to be driving policy in Buenos Aires. This can only be welcomed by all. 
According to Oliver Williamson, in an economic sense opportunism 'refers to a lack of candor or honesty in transactions, to include self-interest seeking with guile' (Williamson I975, 9). Political realists would certainly agree with that as would many writers on strategic studies. The object of policy and strategy is to achieve self (national) interest using all the lever of power, including some aspects of guile. If 'a lack of candor or honesty in transactions' drives UK policy in the South Atlantic, or it is seen to be, then a blossoming relationship with Argentina will fall apart amid cries of British colonialism / imperialism and the memories of British intervention and informal empire during the nineteenth and twentieth centuries. So the UK has to be genuine, even in transactional relationships. Supporting Susana Maclorra's failed bid to become the UN Secretary General can be seen as part of being a credible partner, as can UK support for Argentina's bid for presidency of the G2O in 2018.

Whatever the character of BREXIT, once there is clarity to Britain's economic and political relationship with Europe, the South Atlantic offers much promise for the UK. Clearly, achieving UK interests in the South Atlantic involves a good working trading relationship with Brazil and Argentina.

Here Antarctica and West Africa come in as areas for further or new collaboration or normalisation between the UK and Brazil and Argentina beyond the Falkland Islands. So while the Falkland Islands have been seen as a strategic gateway into the region, the posit here is that the UK Overseas Territories in the South Atlantic cement the UK not as an external actor, but instead as an actor with direct, tangible interests in the South Atlantic. This is important when we come back to the fact that for the UK economic interests in the South Atlantic are mainly focused on Brazil and that country is the leading regional power with ambitions beyond the South American continent.

Hence while the UK has had a tendency to focus on the Argentine relationship, viz-a-viz the Falkland Islands, that also cannot be separated from Argentine-Brazilian relations and UK-Brazilian relations. They are all part of the same context and important because actors and roles are relative to context and to other actors. If we consider Brazil playing a role encompassing autonomy from global powers (evidenced by ZPCAS), as a regional leader, and as an influential power (upholder of the rule of law) - it all gives Brazil much in common with the UK. Both are keen to uphold an international rules based order, to be good global citizens and to respect the sovereignty and rights of peoples.

Brazilian capacity building in West Africa can be seen as a derivative of ZPCAS, to minimise the presence and need for external actors to enhance African security. Here the UK also has an interest in those six African countries 
with African coastlines of which South Africa (along with India and Brazil form IBSA) and Namibia have strong links to Brazil (Goldoni and Nazareth Ciribelli 20I6, I95-8). Moreover, existing Brazilian security architecture, such as India-Brazil-South Africa Maritime exercises, includes two commonwealth countries. Opportunities for British involvement here are limited, with the UK Royal Navy light on resources for the South Atlantic and Antarctic Patrols with just HMS Clyde and HMS Protector deployed. Despite that the UK has been involved in an ad-hoc basis with humanitarian crises in West Africa, such as the Ebola outbreak of 2013-2016 where the UK deployed I,500 military personnel. Without a sustained presence and enhanced capacity, further opportunities for collaboration with the powers of the South Atlantic will be limited to ad-hoc responses.

For Brazil the biggest issues are non-state such as, transnational crime including the narcotics smuggling, possible threats to oil supplies and piracy. But Brazil, with its proposed changes to the continental shelf, has also been taking a realist, power centric approach to resources, to guarantee exclusive access to untapped maritime resources in the South Atlantic. The means have been applications to the UN about the continental shelf, the reconstitution of ZPCAS and working with other southern hemisphere powers such as South Africa and India. So Brazil, while possessing an ambitious (perhaps over-ambitions) defence strategy is also looking to exercise power through international security architecture to promote national interests and to deter the influence or involvement of external other powers including the USA, NATO, UK but also China and Russia. Brazil clearly sees itself leading South Atlantic Security. That is important as many non-state security concerns overlap between Brazil and Argentina, for example the Bolivian drug route.

So in this environment what can the UK do to further its national interests? ZPCAS itself and some South Atlantic countries are not keen on formal UK involvement in the region, but there is certainly scope for enhanced bilateral and informal links between the UK and Argentina and Brazil in terms of knowledge sharing, best practice and capacity building to deal with security concerns. Of value here is the UK Defence attaché network promoting shared education, research, teaching, best practice, applied strategic thinking, doctrinal understanding and the presence of Brazilian and Argentine officers on Professional Military Education courses in the UK.

This all raises the issue of a renewed UK interest in soft power, which was the subject of the House of Lords Committee on Soft Power and the UK's Influence appointed in May 2013 to report on the subject. This chimes with the Brazilian approach, as Mr Roberto Jaguaribe, the Brazilian Ambassador to the UK, noted in evidence to the Committee 'Brazil has perhaps been oc- 
casionally recognised as the first big soft power because we do not have hard power' (House of Lords 20I5, Q.I87). Mr Jaguaribe went on to tell the Committee:

Brazil has had the opportunity over the past 30 or 40 years to consolidate the perception of being among the leading countries of the emerging, developing world. That generates a lot of positive benefits, such as hosting the Olympic Games or the World Cup. We were chosen because we generate good will in the people who are choosing. The candidates from Brazil tend to be elected. Brazil tends to be elected in all multilateral elections. All that has an effect...(House of Lords 2015, Q.I95)

Interestingly the UK has ramped up its soft power initiative with Brazil. In October 2015 both countries confirmed the that the Newton Fund, to tackle global challenges including infectious and neglected diseases, sustainable agriculture, issues on water, waste and energy across Brazil, will be funded to the value of $£ 45$ million by each partner. Enhanced academic links between UK and Brazilian educational institutions to share knowledge, provide staff and student educational visits and to formulate and deliver collaborative research projects are already in place to address global issues that impact upon both countries and areas of mutual concern, like the South Atlantic. This is crucial work for the benefit of all, and the UK and Brazil can lead the way in a manner that UK does not link in currently with Argentina. There the election of President Macri is further evidence of a move in South American politics from the left towards the centre ground (IISS 20I6, 245-7).

\section{Conclusion}

When set against the UK leaving the EU through BREXIT and uncertainty over the future economic relationship with the USA, it is timely for the UK to look to South America. Business and economic benefit are the driving forces and the UK is clearly on the right tack, but UK policy makers need to think about how they can do more in many areas with the countries and peoples of South America. That is because a failure to act will not only harm the UK's strategic perspective on its interests in the South Atlantic, others, such as the USA, China and Russia, will, and indeed, are acting to secure lucrative trade. So while a policy based around the concept of upholding the status quo might be sensible in terms of hardnosed realism that does not necessarily mean doing nothing. Issues of dispute can be worked around, or even worked through to the benefit of all involved, the key being to focus on 
areas where all interested parties can benefit. If that sees the UK taking on the role of an opportunistic actor, then so be it. But out of that there is some certainty. Maintaining a strong relationship with Brazil will be essential for the UK's interests in the region in a post BREXIT world, as will forging closer economic links with Argentina.

\section{REFERENCES}

Abdenur, A.E. and Danilo M. de Souza Neto. 2013. Brazil's Maritime Strategy in the South Atlantic: The Nexus Between Security and Resources, South African Institute of International Affairs, Occasional Paper i6r. http:// www.saiia.org.za/occasional-papers/463-brazil-s-maritime-strategy-in-the-south-atlantic-the-nexus-between-security-and-resources/ file. Accessed on March 24, 2017.

Benwell M.C., and Alasdair Pinkerton. 20I6. "Brexit and the British Overseas Territories: Changing Perspectives on Security" RUSI Journal, r6r:4

Brozoski, F.P. De Campos, and Rodrigo Padula. 20ı6. "Maritime Geopolitics as a Strategic Factor for Regional Integration in South America" Austral: Brazilian Journal of Strategy \& International Relations 5:I0

Clegg, P. 20I6. "Brexit and the Overseas Territories: Repercussions for the Periphery". The Roundtable I05:5

Dockrill, S. 2002. Britain's Retreat from East of Suez: The Choice between Europe and the World? Basingstoke: Palgrave Macmillan.

Dodds, K. 20I2:I. "The Falkland Islands as a 'Strategic Gateway", RUSI Journal $\mathrm{5} 57: 6$

Dodds, K. 20I2:2. "Stormy waters: Britain, the Falkland Islands and UK-Argentine relations". International Affairs 88: 683-700

Duarte É. 20I6. "Brazil, the Blue Economy and the maritime security of the South Atlantic". Journal of the Indian Ocean Region I2:I

European Commission. 20I6. http://ec.europa.eu/trade/policy/countries-and-regions/regions/mercosur/index_en.htm. Accessed on March 24, 2017.

The Falklands War. 2002. Seminar held 5 June 2002 at the Centre for Contemporary British History. http://www.icbh.ac.uk/witness/falklands/. Accessed on March 24, 2017.

Freedman, L. and Gamba-Stonehouse, V. I991. Signals of War: The Falklands Conflict of 1982. Princeton: PUP.

Gaskarth, J. 20I4:I. “Strategizing Britain's role in the world”. International 
Affairs, 90: 3

Gaskarth, J. 20I4:2. "The National Interest and Britain's Role in the World", In British Foreign Policy and the National Interest: Identity, Strategy and Security, edited by Edmunds T., Gaskarth, J., Porter R. Palgrave Macmillan.

Goldoni, L.R.F., and Sandro de Nazareth Ciribelli. 20I6. "Relations of Brazil with South Africa and Angola: efforts for the maintenance of security in South Atlantic", Austral: Brazilian Journal of Strategy Q International Relations, 5:9.

Goñi, U. 20I6. "Argentina protests to Britain about military exercises in Falklands". The Guardian. October I4, 20I6. https://www.theguardian. com/world/20I6/oct/I4/argentina-protests-britain-military-exercises-falklands. Accessed on March 24, 2017.

Griffin, S. 2005. Joint Operations: A Short History. Upavon: UK DCDC.

HM Revenue and Customs. 20I7. "UK Overseas Trade Statistics January 20I7". https://www.uktradeinfo.com/Statistics/OverseasTradeStatistics/Pages/EU_and_Non-EU_Data.aspx Accessed on March 24, 2017.

Hermann, M.G. I987. "Foreign policy role orientations and the quality of foreign policy decisions", In Walker, S.G., (ed.), Role theory and foreign policy analysis. Duke University Press.

Her Majesty's Stationery Office. 20I5. National Security Strategy and Strategic Defence and Security Review 2015: A Secure and Prosperous United Kingdom. London.

House of Commons, PASC. 20II. Who does UK National Strategy? Further Report, UK House of Commons Public Administration Select Committee (2OII), 4. https://www.publications.parliament.uk/pa/cm2OIoII/ cmselect/cmpubadm/7I3/713.pdf. Accessed on 24, 2017.

House of Lords. 2015. Oral evidence, Mr Roberto Jaguaribe. http://www.parliament.uk/documents/lords-committees/soft-power-uk-influence/ soft-power-ev-voli-a-g.pdf. Accessed on March 24, 2017.

Holsti, K. J. I970. "National Role Conceptions in the Study of Foreign Policy". International Studies Quarterly, I4: 3.

McCourt, D.M. 20I4. Britain and World Power since 1945: Constructing a Nation's Role in International Politics. Ann Arbor: University of Michigan Press.

MercoPress. 20I6. "Malvinas is no impediment for dealing with UK, but Islands population can't be denied". MercoPress, November ı०, 2016. http://en.mercopress.com/20I6/II/ıo/malvinas-is-no-impediment- 
for-dealing-with-uk-but-islands-population-can-t-be-denied. Accessed on March 24, 2017.

Mitchell, C. 20I4. The Nature of Intractable Conflict: Resolution in the Twenty-First Century. Basingstoke: Palgrave Macmillan.

IISS, (20I7), The Military Balance, II7 :I

2016. "Latin America”. Strategic Survey II6:I

NATO (I949), http://www.nato.int/cps/en/natohq/official_texts_I7I20.htm. Accessed on March 24, 2017.

Office For National Statistics (ONS). 20I5. "How important is the European Union to UK trade and investment?". http://www.ons.gov.uk/ons/ rel/international-transactions/outward-foreign-affiliates-statistics/index.html. Accessed on March 24, 2017.

20I6. "The UK's trade and investment relationship with South America: 2016". https://www.ons.gov.uk/economy/nationalaccounts/ balanceofpayments/articles/uktradeandinvestmentwithsouthamerica/20I6. Accessed on March 24, 2017.

. (2OI7:I) "Who does the UK trade with?". February 2I, 20I7. http:// visual.ons.gov.uk/uk-trade-partners/. Accessed on March 24, 2017. (2OI7:2) “The UK's trade and investment relationship with South America: 2016". https://www.ons.gov.uk/economy/nationalaccounts/balanceofpayments/articles/uktradeandinvestmentwithsouthamerica/2016. Accessed on March 24, 2017.

. (20I7:3), "UK trade: Jan 20I7". https://www.ons.gov.uk/economy/ nationalaccounts/balanceofpayments/bulletins/uktrade/jan20I7. Accessed on March 24, 2017.

Oliver, T. and Michael J. Williams. 20I6. "Special relationships in flux: Brexit and the future of the US-EU and US-UK relationships". International Affairs, 92: 547-567

Oxford Economics. 20I6. "Fragile recovery in Q4 20I6, highlighting downside risks for growth forecast of $2.5 \%$ in 2017 ". http://www.oxfordeconomics.com/my-oxford/publications/360866. Accessed on March 24, 2017.

Platt, D.C.M. I972. Latin America and British Trade, 1806-1914. London: Adam and Charles Black.

Ringland, G. 2006. Scenario planning: managing for the future. Chichester: Wiley.

Robson, M. 20I0. Britain, Portugal and South America in the Napoleonic Wars: Alliances and Diplomacy in Economic Maritime Conflict. London: I.B. 
Tauris.

Swinford, S. 2015. “Jeremy Corbyn's Falklands plan tantamount to surrender to Argentina, warns wounded veteran Simon Weston”, The Daily Telegraph, August 29, 20I5. http://www.telegraph.co.uk/news/politics/II833264/Jeremy-Corbyns-Falklands-plan-tantamount-to-surrender-to-Argentina-warns-wounded-veteran-Simon-Weston.html. Accessed on March 24, 2017.

UK Government. 20I5. https://www.gov.uk/government/publications / 2 OIO-to-2OI 5-government-policy-uk-overseas-territories/20Io-to-20I5-government-policy-uk-overseas-territories\#issue. Accessed on March 24, 2017.

20I6:I. https://www.gov.uk/government/news/uk-and-argentina-agree-joint-statement-on-areas-of-mutual-cooperation. Accessed on March 24, 2017.

20I6:2. https://www.gov.uk/government/news/trade-minister-hails-renewed-relationship-with-argentina-with-trade-mission. Accessed on March 24, 2017.

. 20I6:3. https://www.gov.uk/government/news/foreign-office-minister-sir-alan-duncan-arrives-in-argentina-for-bilateral-talks. Accessed on March 24, 2017.

. 2оI6:4. https://www.gov.uk/government/news/uk-response-to-argentinas-intention-to-extend-its-continental-shelf. Accessed on March 24, 2017.

UN data. 20I5. http://data.un.org/CountryProfile.aspx?crName=BRAZIL. Accessed on March 24, 2017.

United Nations Charter. I945. http://www.un.org/en/sections/un-charter/ chapter-i/. Accessed on March 24, 2017.

Wiesebron, M. 2013. "Blue Amazon: Thinking The Defense of The Brazilian Maritime Territory”. Austral: Brazilian Journal of StrategY Q International Relations, 2:3

Williamson, O.E. I975. Markets and hierarchies: analysis and antitrust implications: a study in the economics of internal organization. London: Collier Macmillan.

Yeomans, J. 20I6. "After Brexit, can the UK build its trade ties with Latin America?", The Telegraph, August I4, 2016. http://www.telegraph. co.uk/business/2016/08/I4/after-brexit-can-the-uk-build-its-tradeties-with-latin-america/. Accessed on March 24, 2017. 


\section{ABSTRACT}

This article assesses the utility of International Relations 'role theory' for understanding the United Kingdom's policy options in the South Atlantic, with specific reference to UK-Argentine relations. The article does not ignore the geo-strategic realities of Anglo-Argentine relations, but posits that recent interactions in the economic sphere can be seen as the beginning of a normalisation process. The cause of this economic rapprochement, it is argued, is less to do with UK policy and instead is due to changes in domestic Argentine politics which have offered a window of opportunity for the UK.

\section{KEYWORDS}

United Kingdom, Policy, Role theory, South Atlantic.

Received on January 5, 2018. Accepted on January 26, 2018. 